\title{
SOME BYGONE POLITICS
}

TWO notable centenaries fall in the present year. On August 6th, I22I, passed to his reward Dominic Guzman. Almost exactly one hundred years later, in July or September, I321, the world's greatest poet since ancient times left a world which had treated him hardly in order to make trial of the justice of a world he had hymned in almost inspired numbers.

Perhaps to a Catholic it is not fanciful to trace a connection between the two, yet few indeed outside the Church consider what the poet owed to the famigliar di Christo and his sons, whose praises are written in the greatest of his works. Dante Aligheri was born in 1265 ; he was a child of nine when Thomas Aquinas died, a boy of fifteen when the Doctor Universal, Albertus Magnus, passed to join his great pupil. His days were passed in wild times. The year of his birth saw the long strife in England between king and baronage culminate in the battle of Evesham, saw Manfred, king of Naples and Sicily, defeated and slain by Charles of Anjou. He was seventeen years old when the bad blood between Frenchman and Neapolitan found outlet in the Sicilian Vespers and the weary reign of anarchy which followed. In I3IO, he saw the suppression of the Order of Knights Templars (so typical a product of the age of faith and chivalry), and in the prime of his years he lived amid the wars and rumours of wars, the intrigues, the treacheries in which his native Florence was involved, the long-drawn-out strife of Guelph and Ghibelline.

On all sides the old order was passing and many of the mediæval theories becoming empty of meaning. The glory which had surrounded the Holy Roman Empire seemed waning, while powerful nation-states arose to dispute its supremacy. The Papacy itself, instead of standing above the turmoil, dictating to 


\section{Some Bygone Politics}

monarchs, loving justice and hating iniquity, had stooped " to vile conclusion," and the shadow not of Canossa but of Avignon lay over Christendom. The desire to find some issue out of both spiritual and temporal troubles had led many to formulate new or to revive old schemes of governance (some strange and new indeed, for desperate evils need desperate remedies) and Dante was fain to add one more. He took some part in actual warfare, but his chief service to his party lay in more diplomatic negotiations (the final failure of which hastened his end) and supremely in his wielding of the pen. The Divina Commedia, because it is itself, has almost eclipsed his other works. Few but Dante enthusiasts read the Vita Nuova and the Convito, and not many find pleasure in the famous De Monarchia. Yet since he is so often claimed as one of those enlightened " Reformers before the Reformation," whose works are a standing witness to the corruption of the Church in general and the Popes in particular, to the decay of genuine piety, and to the righteous opposition of temporal rulers to papal tyranny, it may not be time lost to enquire what Dante really did think and say about Empire and Papacy and whence he gathered some of his ideas.

Of the Friars, especially of the Dominicans, he was an ardent admirer, of their greatest works a close student, and much Dominican lore can be traced even in a book for which " that blest flock which Dominic so leads in righteous ways" would claim no brief. He begins by saying that man, on whom " higher nature has impressed the love of Truth," should labour for others and should expend his toil on some truth not yet unveiled to men, so saint and poet meet in their ideal -Veritas-though prejudice and bitterness sometimes obscure the latter's vision. He elects to treat of "temporal monarchy" by which he understands the Empire which is " government of one prince above all 


\section{Blackfriars}

men in Time," with " no reference to worldly gain." He proposes his theses thus : Is temporal monarchy necessary for the welfare of the world ? Did the Roman people by right take to itself the office of monarchy? Does this monarchy come from God Himself or from His Vicar?

True pupil of the Dominicans he begins at the beginning. What is the object of man, what that of the State? For the first he refers us to St. Thomas.* "It is to be percipient with the possibility of understanding " ; the object of the State is universal peacebut something more. The sublime mediæval concept comes in, "All is well and at its best which exists according to the Will of the First Cause, God ; " the whole universe is but the footprint of Divine goodness," and he sums it up in the oft-quoted passage, "Unity is God and the State is likest God $\dagger$ when it is one." (Is it a far-distant prelude to Lacordaire's " Every nation is a ship whose anchors are cast in Heaven" - the cry of another seer in another age of chaos which knew not how to obey?) Only under the rule of a single monarchy can this unity come about. In this State peace can reign, but only on a basis of Justice strengthened by Charity. Like St. Thomas he prefers monarchy, but likewise he stresses the condition that the ruler must be virtuous. With a dogmatism born of bitter experience he denounces Democracies, Oligarchies, and forms of government which he says drive into slavery, and concludes his train of reasoning with a phrase taken nearly verbatim from his master, "The citizen exists not for the good of consuls nor the nation for the good of the king, but the king for the good of the nation."

Proceeding to his second query, he tells us that once he saw in the triumph of old Rome only a victory of

* " apprehensum per intellectum possibilem," I. I79, I, 2, I0.

+ Conferences on "Life" given at Toulouse.

368 


\section{Some Bygone Politics}

arms, now he sees Divine providence-Digitus Dei est hic. Here, as nowhere else, comes out the love of the Renascence Humanist for the ancient world. Virgil himself loved not more that City of the Cæsars, predestined to rule the world, to impose its healing "Pax Romana," "Parcere subiectis et debellare superbos," than does his fellow-bard who hailed that same dominion now become the City of God. Dante is distressed because others cannot see it too: "I grieve that kings and princes agree only in opposing their Lord and His one only Roman Emperor." He puts the query whether God willed the Roman supremacy, and answers thus: "That which is helped by miracles is willed by God," as St. Thomas says in his third book against the Gentiles - ' a miracle is something wrought by God beyond the commonly established order of things,' * the Roman Empire was helped to its perfection by miracles," ergo. . . . We cannot follow him in his journeyings through mythology and ancient history to prove the divine right of the Emperor, but at the end he is too good a Catholic not to qualify his Ghibellinism and we have, "To whom God makes the grant, him let Peter also bless."

The third section shows his anti-papal views of temporal monarchy. He complains of the nepotism of his days, that crying sin of the typical Renascence pontiffs, of the seizing and alienating of Church revenues and patrimonies which are held in trust for the poor, but he goes on to say that these should never have been bestowed upon the Papacy as a gift since the Emperor receives the Empire as a sacred trust and has no power to alienate it-like the Church, the Empire is " a seamless robe" not to be rent. He seems always careful to vindicate his own orthodoxy, he speaks of " the Vicar of God by whom I understand the successor of Peter, who only has the keys of the kingdom of

$$
\text { * Contr. Gent. iii. Ior. }
$$

$2 \mathrm{~B}$ 


\section{Blackfriars}

Heaven." He says some oppose his views from mistaken zeal for mother Church. He treats of the theory of the " two great lights," and argues that though the Emperor needs the divine strength gained by the benediction of the Supreme Pontiff, to state, as some of his opponents do, that the Pope has all power " whatsoever" is to prove too much and so prove nothing. He illustrates by an example surely of pregnant force to-day. "If ' whatsoever' meant ' absolute all,' the Pope could then divorce a wife from her husband and marry her to another-which he can in no wise do." To Dante such a state of things is a final reductio ad absurdum!

He develops his theory thus. The Empire preceded the Church, therefore it cannot owe its existence to the Church. Christ's kingdom is not of this world, He made no arrangement for a temporal sovereignty and the Church cannot change her pattern now, "It belongs to the very form of the Church always to speak, always to think the same." (One admires the orthodoxy more than the logic !). He continues, elaborating the idea, and closes with a fine passage : "Two ends have been laid down for man, one the blessedness of this life which consists in the exercise of his natural powers, the other the blessedness of life eternal which consists in the vision of God. Man therefore needs two guides, the Supreme Pontiff to lead him to eternal life, the Emperor to guide him to happiness in this." Let therefore Cæsar be reverent to Peter as the firstborn son to his father, that he may be illumined with the light of his father's grace, and so may be stronger to enlighten the world over which he has been placed by His choice Who is Ruler of all things, spiritual as well as temporal.

Now to consider where Dante stands among mediæval Political Philosophers. The Golden Age of the Papal monarchy is that of Innocent III, the watch- 


\section{Some Bygone Politics}

word of the real mediævalists, "Sedes Apostolica omnes judicat et a nemine judicatur" applied in the strictest possible way. It utters its most poignant farewell in the Bull Unam Sanctam (no wonder the author of De Monarchia placed Boniface VIII in Hell !). On the other hand, even before Dante, there arose another school, the advocates of popular sovereignty, who maintained that, far from the Pope having a plenitude of earthly dominion and the Emperor being merely a delegate, the final court of appeal lay in the People. 'They explained Charlemagne's coronation as follows : the Greek Emperor had forfeited the empire, it reverted to the Roman people, who delegated it to Charlemagne, the Pope who crowned him merely executing the popular will. Cusa is infected with the doctrine, Occam more so, Marsiglio of Padua most of all. The Cardinal is too good a Catholic to go very far, but the other two push the idea of popular sovereignty to the extreme limit, apply it to the Church as well as the State and make the Pope's infallibility conditioned by a General Council.

Dante belongs to neither party. He keeps fairly close to St. Thomas and would have the temporal prince submissive to the Pope in all things spiritual; he shares the Angelic Doctor's views about temporal rule which is not ordained to the public good, but Dante has his vision limited. St. Thomas lays down great principles of governance for all times and all nations and does not concern himself with the superexcellence of the Empire though he was born its subject. It is noteworthy that more than one Ghibelline is found among the Dominican thinkers of the troubled period, probably Eckehart and many of the circle under his direction, and certainly Tauler who, living in Germany from 1290 to $136 \mathrm{r}$, saw as much of the struggle as did the poet in his southern home. Always Dante looks to the Dominicans; he quotes St. Thomas 


\section{Blackfriars}

at every turn, the arrangement of his matter, his phrases saturated with Scholastic Philosophy and Theology are all eloquent of his reverence for the "Loving minion of the Christian Faith" and his sons, so few of whom fall away that " a little stuff may furnish out their cloaks." He himself is a true son of the Ages called of Faith, he disapproves of some popes as men, never as popes. True he places four in Hell, at least, but studying their careers one sees it is for their political acts rather than their spiritual failings that they are there-even when railing at Nicholas III the poet speaks of his own "reverence for the keys" * ; again he reverences Adrian V "with inward awe of your high dignity." † He sees St. Dominic supremely as one who was " fit colleague to keep the bark of Peter in deep sea, helmed to right port." $\mathrm{He}$ is no " $\mathrm{Re}$ former," he is not even purely a son of the Renascence, he is rather a last voice of a better age, describing an ideal Empire, what he would wish to see rather than what he hoped, a pleader for a kingdom of this world become the kingdom of God and His Christ, for an earthly realm that should yet look for its guidance, and in things spiritual for its dominion to the City set on the Seven Hills-in an age of violence, of sophistry, of dawning heresy a voice crying in the wilderness.

Dorothea E. Brennell.

* Inferno XIX, 7I. + Purgatorio XIX, 7I. 